\title{
Pelatihan Proses Pembuatan Kompos Dari Sampah Organik Di Smp Muhammadiyah Dumai
}

\author{
Trisna Mesra ${ }^{1}$, Melliana ${ }^{2}$ Fitra $^{3}$ \\ 1,2,3 Program Studi Teknik Industri, Sekolah Tinggi Teknologi Dumai \\ *e-mail: trisnamesra74@gmail.com¹, mellianna52@gmail.com, famukhtyfitra@gmail.com
}

\begin{abstract}
This Community service Program is in partnership with Muhammadiyah Dumai Middle School. This community service program is very important to implement because it will help children improve their knowledge and skills in the process of making organic compost. So that junior high school students can practice at school and at home and tehe environment they are in. Where this compost can be used for ornamental plants in school and vegetable plants in the homes of each student. With the iplementation of this community service program, the community service team at the Dumai College of Technology provide skills on how to make compost by utilizing leaves from trees at scholl and this is a provision of knowledfe for them if they have lived a life later.
\end{abstract}

Keywords: process, compost, organic

\begin{abstract}
Abstrak
Program Pengabdian Masyarakat ini bermitra dengan Sekolah Menengah Pertama Muhammadiyah Dumai. Program pengabdian masyarakat ini sangat penting untuk dilaksanakan dikarenakan akan dapat membantu anak-anak untuk meningkatkan pengetahuan dan keterampilan proses pembuatan kompos organik. Sehingga siswa-siswi SMP bisa mempraktekkan di sekolah dan dirumah serta lingkungan mereka berada. Dimana kompos ini akan dapat dimanfaatkan untuk tanaman hias di sekolah dan tanaman sayuran dirumah siswa masing- masing. Dengan terlaksananya program pengabdian masyarakat ini, tim pelaksana pengabdian kepada masyarakat Sekolah Tinggi Teknologi Dumai memberikan skill tentang cara pembuatan kompos dengan memanfaatkan sampah-sampah dedauanan yang berasal dari pohonpohon di sekolah dan ini merupakan salah satu bekal pengetahuan bagi mereka apabila mereka telah menjalani kehidupan nantinya.
\end{abstract}

Kata kunci: proses, kompos, organik

\section{PENDAHULUAN}

Sekolah Menengah Pertama Muhammadiyah adalah salah satu sekolah yang ada di kota Dumai yang berada di bawah naungan Muhammadiyah beralamat di jalan S.M. Amin No 108 Kelurahan Jaya Mukti Kecamatan Dumai Timur yang berjarak 6 Km dari Sekolah Tinggi Teknologi Dumai yang dibina oleh Ibu Dra.Asmawati, dimana jumlah siswa di sekolah ini berjumlah lebih kurang 300 orang dengan tingkat tingkat pendidikan kelas VII 2 rombel, kelas VIII 3 rombel dan kelas IX 3 rombel yang belajar dari jam 07.00 sampai Jam 13.30 WIB.

Siswa -siswa di SMP Muhammadiyah hanya mendapatkan pendidikan formal sesuai dengan kurikulum nasional tanpa adanya pendidikan extra berupa tambahan ilmu berupa keterampilan yang bisa diaplikasikan nantinya. Oleh sebab itu maka tim pengabdian masyarakat STT Dumai akan memberikan skill dan keterampilan diantaranya : 1) Teori atau cara pembuatan kompos dari sampah organik 2) Mempraktekkan cara pembuatan kompos dari sampah organik.

Tujuan dari pengabdian masyarakat di Sekolah menengah Pertama Muhammadiyah Kota Dumai adalah :

1. Mitra memiliki pengetahuan tentang cara-cara pembuatan kompos

2. Mitra memiliki keterampilan dalam proses pembuatan kompos dari bahan organik. 
Suwatanti (2017), melakukan pemanfaatan MOL limbah sayur pada proses pembuatan kompos dan mengatakan bahwa kualitas kompos yang menggunakan limbah sayur lebih baik C/N ratio dibanding menggunakan EM4. Sementara Evaluasi pembuatan kompos organik dengan menggunakan metode hot composting dilakukan oleh Budi Utomo (2018) dan menghasilkan bahwa pembuatan kompos menggunakan limbah sayur kubis yang berperan sebagai unsur nitrogen dan daun kering sebagai unsur karbon. Proses pembuatan kompos dengan melihat perbandingan jumlah kotoran sapi yang berbeda pada perlakuan pengomposan berpengaruh pada kecepatan proses pengomposan dan kualitas hasil proses pengomposan dilakukan oleh Sebastian dkk (2016). Pengelolaan sampah rumah tangga melalui pembuatan pupuk kompos metode Takakura di lingkungan tempat tinggal agar meminimalisir efek kesehatan dan lingkungan dari kegiatan pengelolaan sampah yang buruk dengan cara di bakar dilakukan oleh Izza Hananingtyas dkk (2020). Pembuatan pupuk kompos padat limbah kotoran sapi dengan metoda fermentasi menggunakan Bioaktivator sturbio sangat bermanfaat dan dapat menunjang ekonomi masyarakat dilakukan oleh Sutrisno.E dan Priyamda ika bagus (2019). Menurut Veronika N dkk (2019) pupuk kompos terbaik diperoleh pada perlakuan batang sawit dan POME dengan perbandingan komposisi yaitu 3:10:2:1 \%(b/b) dengan karakteristik, nilai kadar air 16,30\%, total NPK 6,08\%, kandungan C-organik 44,10\%, rasio $\mathrm{C} / \mathrm{N}=16,30$ dan $\mathrm{pH} 8,16$. Karakteristik pupuk kompos yang dihasilkan telah memenuhi standar Peraturan Menteri Pertanian No. 70/Permentan/SR. 140/10/2011. Pengomposan TKS (Tandan kosong sawit) merupakan cara untuk meningkatkan dan menyehatkan tanah dan tanaman kelapa sawit, serta mencegah berkembangbiaknya kumbang tanduk (Oryctes rhinoceros) pada perkebunan kelapa sawit dilakukan oleh Firmansyah M.A (2010).

\section{METODE}

Metode pelaksanaan pada pengabdian masyarakat (PPM) adalah mengadakan pemberikan pengetahuan tentang metoda metoda yang digunakan dalam proses pembuatan kompos dan mempraktekkan proses pembuatan kompos dari sampah organik di sekolah menengah pertama Muhammadiyah kota Dumai. Proses pelaksanaan pelatihan antara lain:

1. Pembuatan Modul dan persiapan material serta peralatan

Sebelum pelatihan dilaksanakan terlebih dahulu tim PPM membuat modul yang akan digunakan dalam proses pelatihan dan membeli bahan-bahan sebagai bahan dasar untuk pembuatan kompos.

Pelatihan dilaksanakan pada Sekolah Menengah Pertama Muhammadiyah Kota Dumai di Jl. S. M Amin Kelurahan Jaya Mukti. Materi pelatihan diberikan oleh tim PPM. Setiap pertemuan dilaksanakan dalam waktu 90 menit.

Materi pelatihan meliputi :

2. Pemberian teori dan pemahaman tentang metoda-metoda pembuatan kompos Dengan cara menjelaskan gambaran menyeluruh tentang proses pembuatan kompos dan manfaat kompos dalam bercocok tanam.

3. Pelaksanaan praktek langsung proses pembuatan kompos dengan melibatkan siswa siswi kelas IX A SMP Muhammadiyah.

\section{HASIL DAN PEMBAHASAN}

Pelaksanaan kegiatan PPM dengan judul "Pelatihan Proses Pembuatan Kompos Dari Sampah Organik Di Sekolah Menengah Pertama Muhammadiyah" telah selesai dilakukan. Berikut ini merupakan hasil yang dicapai dalam pengabdian ini. 
ABDINE: Jurnal Pengabdian Kepada Masyarakat Vol. 01, No.01, Juni 2021, Hal. 1-7

p-ISSN 2798-2882, e-ISSN 2798-2890

Tabel 1. Kegiatan Pengabdian dan Hasil Yang Dicapai

\begin{tabular}{|c|c|c|c|}
\hline & Kegiatan & Tujuan & Hasil \\
\hline \multirow[t]{2}{*}{1} & Persiapan & & \\
\hline & $\begin{array}{l}\text { Koordinasi dengan Kepala } \\
\text { Sekolah SMP } \\
\text { Muhammadiyah Dumai }\end{array}$ & Mengajak mitra bekerja sama & $\begin{array}{l}\text { Mitra bersedia } \\
\text { menerima tim } \\
\text { pengabdian } \\
\text { masyarakat }\end{array}$ \\
\hline \multirow[t]{4}{*}{2} & Pelaksanaan & & \\
\hline & a. Sosialisasi Kegiatan & $\begin{array}{l}\text { Mengetahui hal-hal yang akan } \\
\text { disampaikan pada kegiatan } \\
\text { Pengabdian }\end{array}$ & $\begin{array}{l}\text { Pelaksanaan } \\
\text { kegiatan pelatihan }\end{array}$ \\
\hline & $\begin{array}{l}\text { b. Pemberian Teori tenntang } \\
\text { cara-cara pembuatan } \\
\text { kompos }\end{array}$ & $\begin{array}{l}\text { Mengetahui hal-hal yang akan } \\
\text { disampaikan pada kegiatan } \\
\text { pengabdian }\end{array}$ & $\begin{array}{l}\text { Pelaksanaan } \\
\text { kegiatan pelatihan }\end{array}$ \\
\hline & $\begin{array}{l}\text { c. Praktek pembuatan kompos } \\
\text { dari sampah organik }\end{array}$ & $\begin{array}{l}\text { Mengetahui hal-hal yang akan } \\
\text { dipraktekkan pada kegiatan } \\
\text { pengabdian }\end{array}$ & $\begin{array}{l}\text { Pelaksanaan } \\
\text { kegiatan pelatihan }\end{array}$ \\
\hline \multirow[t]{3}{*}{3} & Penutup & & \\
\hline & a. Evaluasi Kegiatan & $\begin{array}{lcr}\text { Mengetahui } & \text { hal-hal } & \text { yang } \\
\text { dianggap perlu } & \text { untuk } \\
\text { perbaikan kedepannya } & \end{array}$ & $\begin{array}{l}\text { Saran untuk } \\
\text { perbaikan kegiatan } \\
\text { pengabdian } \\
\text { selanjutnya }\end{array}$ \\
\hline & b. Laporan kegiatan & $\begin{array}{l}\text { Melaporkan serangkaian } \\
\text { kegiatan pengabdian }\end{array}$ & $\begin{array}{l}\text { Laporan kegiatan } \\
\text { PPM }\end{array}$ \\
\hline
\end{tabular}

Kegiatan pengabdian ini telah dilaksanakan tanggal 17 November 2018 pada Sekolah Menengah Pertama Muhammadiyah Kota Dumai di Jl. S.M. Amin No 108

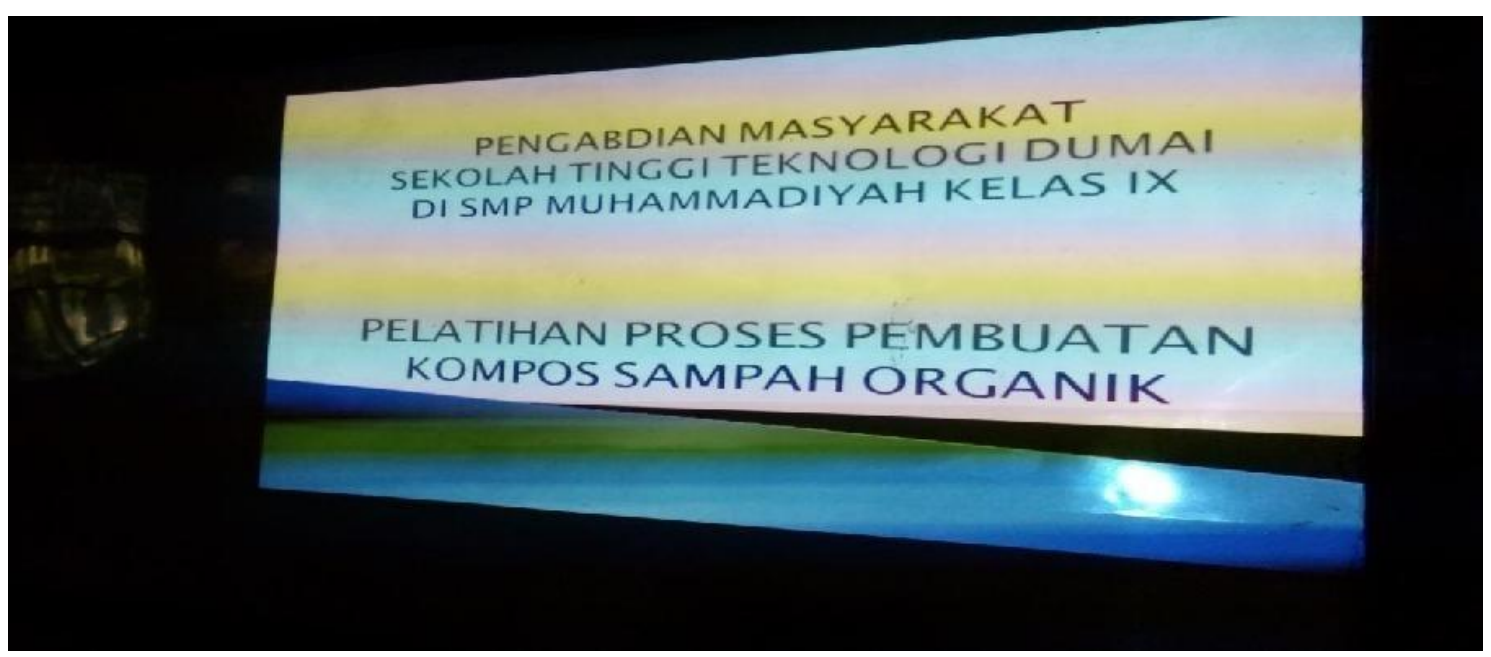

Gambar 1. Materi Pengabdian Masyarakat

Kelurahan Jaya Mukti Kecamatan Dumai Timur. Kegiatan ini diisi dengan materi mengenai cara-cara membuat kompos dari sampah organik dan praktek proses pembuatan kompos dari sampah organik dengan melibatkan siswa-siawi SMP kelas 
IX yang berjumlah lebih 35 orang. Para peserta sangat antusias untuk mengikuti kegiatan ini, dibuktikan dengan kesediaan mereka mendengarkan penjelasan yang disampaikan pemateri dan banyaknya pertanyaan yang diajukan seputar materi yang diberikan. Materi diberikan dalam dua sesi dan diakhiri dengan Tanya jawab dan foto bersama. Materi pertama adalah menjelaskan cara-cara membuat kompos dari sampah organik.

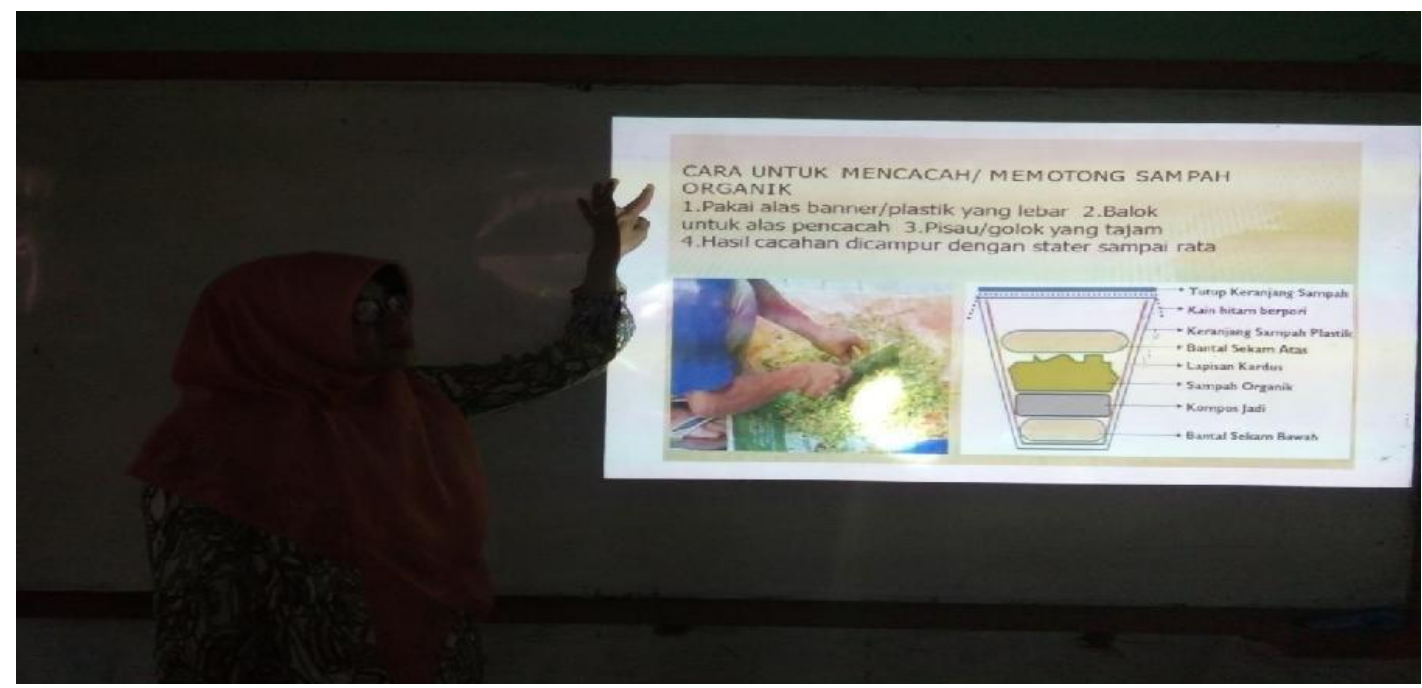

Gambar 2. Materi Cara Pengolahan Sampah Organik

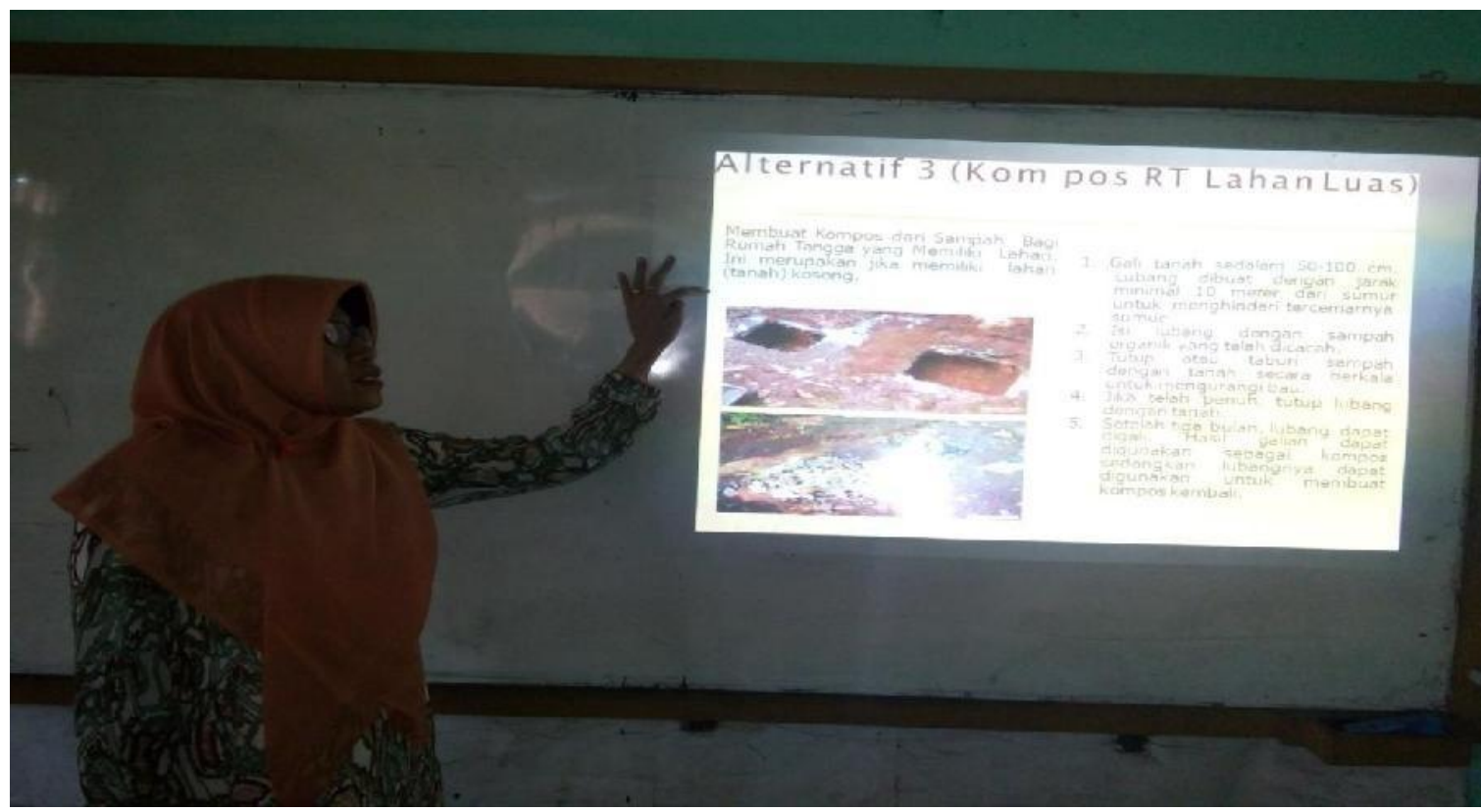

Gambar 3. Penjelasan Cara Pembuatan Kompos Rumah Tangga

Materi kedua yang disampaikan adalah mempraktekkan cara membuat kompos dengan memanfaatkan sampah organik berupa sisa sayuran dan membuat kompos pada lahan yang sempit menurut Sofian (2006). 

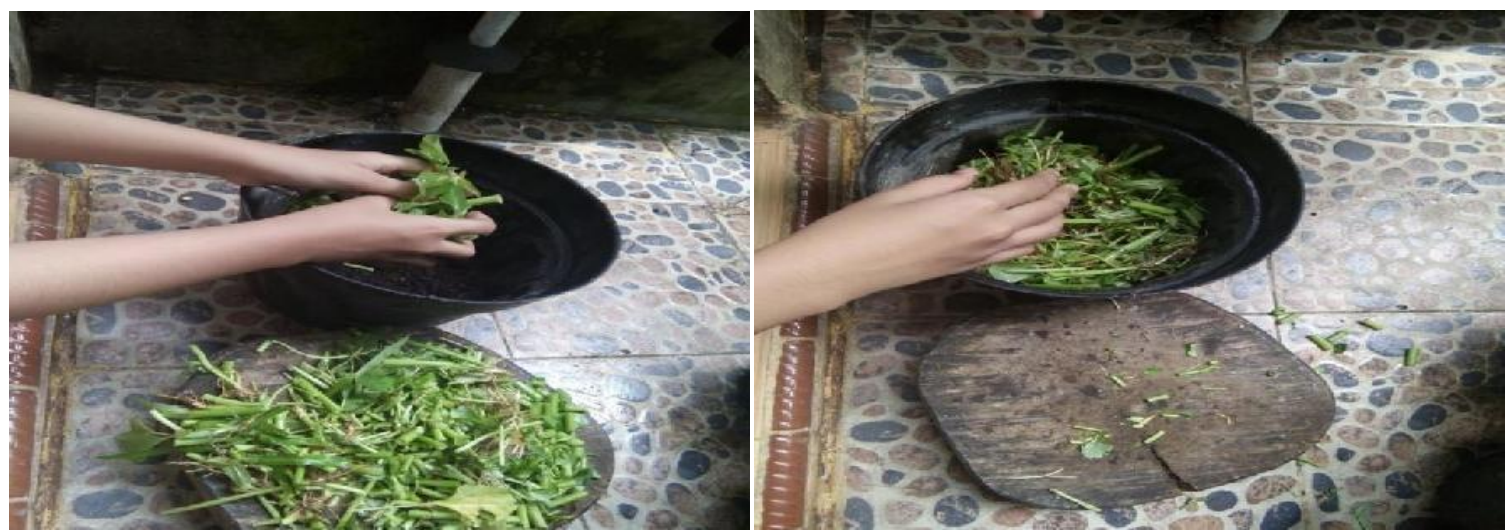

Gambar 4. Tahapan Pebuatan Kompos Pada Lahan Sempit

Setelah praktek proses pembuatan kompos dari sampah organik yang dapat diterapkan dilahan sempit maka dilanjutkan dengan proses pembuatan kompos di lahan yang luas dengan memanfaatkan dedaunan kering

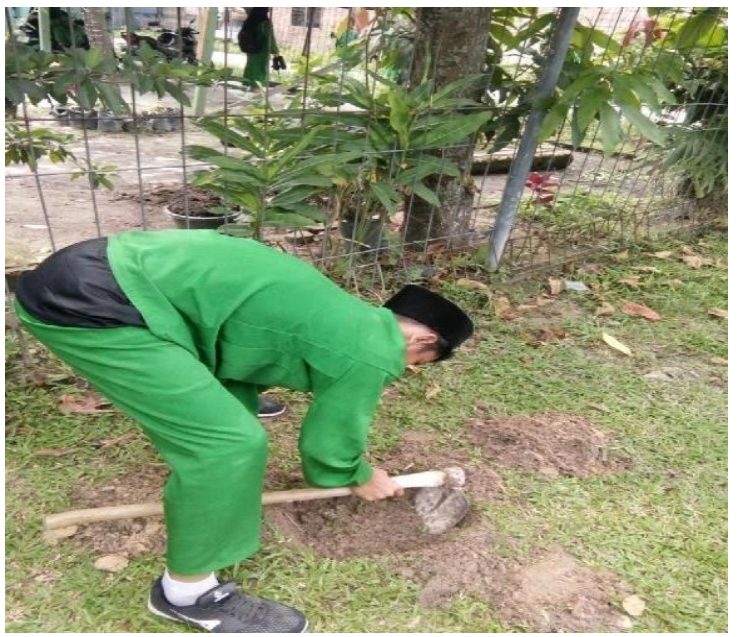

(a)

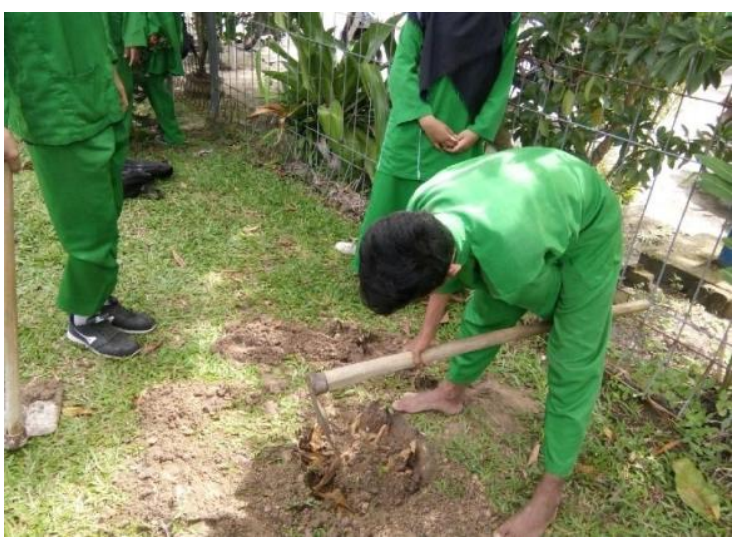

(c)

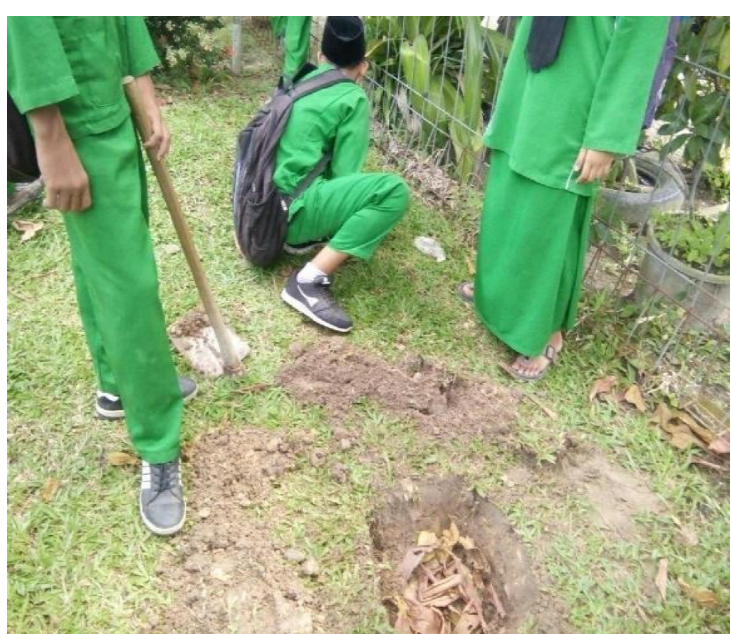

(b)

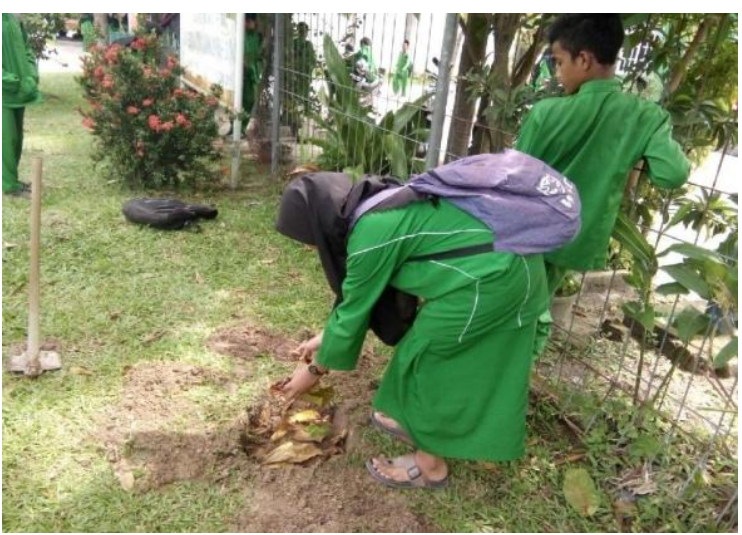

(d) 


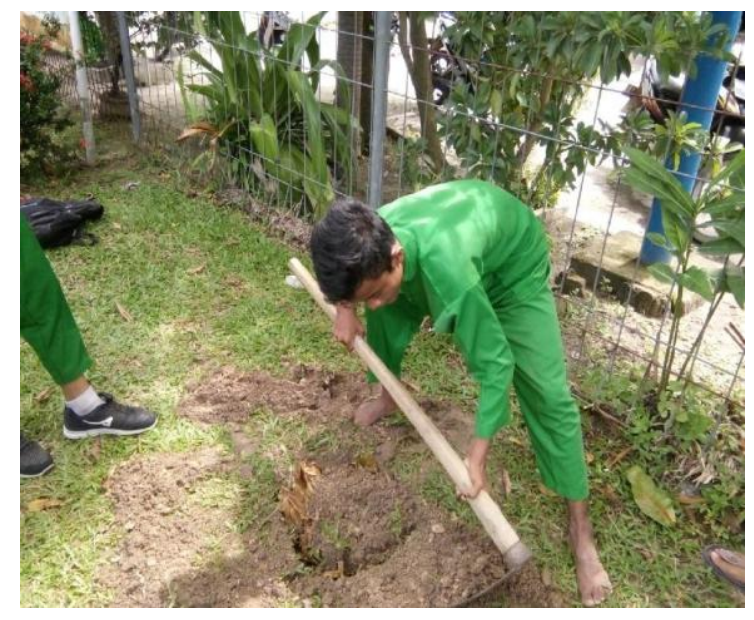

(e)

Gambar 5. Tahapan Pembuatan Kompos di Lahan Luas (a) Penggalian lubang (b) Pengisian sampah kering lapisan pertama (c) Penimbunan tanah pertama (d) Pengisian sampah kering lapisan kedua (e) Penutupan dengan tanah

\section{KESIMPULAN}

Pelatihan proses pembuatan kompos di Sekolah Menengah Pertama Muhammadiyah Kota Dumai untuk meningkatkan pengetahuan dan keterampilan tentang proses pembuatan kompos dari sampah organik dan bisa memanfaatkan sampah menjadi produk yang mempunyai nilai tambah dan mengurangi penumpukkan sampah di Lingkungan sekitar tempat tinggal siswa.

Kedepannya, diperlukan suatu pelatihan yang lebih mendalam untuk meningkatkan keterampilan siswa siswa untuk jenis kegiatan yang lainnya yang bisa menambah pengetahuan praktis tentang pengolahan sampak anorganik menjadi produk-produk yang bermanfaat dan mempunyai nilai jual sehingga bisa menumbuhkan kreatifitas siswa-siawa Sekolah menengah Pertama.

\section{DAFTAR PUSTAKA}

Firmansyah.M.A. (2010). Teknik Pembuatan Kompos. Balai Pengkajian Teknologi Pertanian (BPTP) Kalimantan Tengah.

Hananingtyas Izza. (2020). Implementasi Pengelolaan Sampah Rumah Tangga Melalui Pelatihan Pembuatan Pupuk Kompos., Jurnal As-Syifa, Jurnal pengabdian dan Pemberdayaan Kesehatan Masyarakat, Vol 1 no 2.

Mussa Sebastiao, Setiyo Yohanes dan Widia I Wayan, (2016). Pengaruh Perbandingan Jerami dan kotoran sapi Terhadap Profil Suhu dan Karakteristik Pupuk Kompos Yang Dihasilkan., Jurnak Beta (Biosistem dan Teknik Pertanian) Volume IV Nomor 2.

Simamora, S dan Salundik. 2006. Meningkatkan Kualitas Kompos. Cetakan pertama, Agromedia Pustaka. Jakarta.

Sofian, 2006. Sukses Membuat Kompos dan Sampah. Agromedia Pustaka, Jakarta Sutejo, M. M. 2002. Pupuk dan Cara Penggunaan. Jakarta: Rineka Cipta

Sutrisno Endro dan Priyamda Ika bagus. (2019). Pembuatan pupuk kompos limbah kotoran sapi dengan metoda fermentasi menggunakan Bioaktivator sturbio. Jurnal Pasopati Volume 1 no 2 tahun 2019. 
Suwatanti, EPS dan Widiyaningrum,P.(2017).Pemanfaatan MOL Limbah Sayur Pada Proses Pembuatan Kompos, Jurnal MIPA , 40(1), 1-6

Utomo Budi.(2018). Evaluasi pembuatan Kompos Organik Dengan Menggunakan Metode Hot Composting., e-journals.Ummul.ac.id Volume 2 nomor 01.

Veronika N, Dhora A, dan Wahyuni S. (2019). Pengolahan Limbah Batang Sawit menjadi Pupuk kompos dengan Menggunakan Dekomposer Mikroorganisme Lokal (MOL) Bonggol Pisang. Jurnal Teknologi Hasil Pertanian vol 29 no 2 :154-161. 